\title{
FASILITAS REKREASI INTERAKTIF TANAMAN HIAS DI KEDOYA UTARA
}

\author{
Matthew Alexander ${ }^{1)}$
}

\author{
1)Program Studi S1 Arsitektur, Fakultas Teknik, Universitas Tarumanagara, matthew.jusuf14@gmail.com
}

\begin{abstract}
Abstrak
Kehidupan perkotaan khususnya Jakarta tidak lepas dari kegiatan sehari - hari seperti bekerja, bersekolah, dan lain - lain. Rutinitas yang dilakukan berulang kali menyebabkan orang merasa jenuh dan stress yang kemudian berpengaruh bagi kinerja seseorang, maka dari itu penting adanya aktivitas yang bersifat hiburan untuk melepas penat, dan stress. Di Kedoya Utara interaksi antar sesama tetangga sangatlah kurang dikarenakan rasa enggan dan asing, kurang adanya aktivitas bersama dan tempat untuk berinteraksi menyebabkan kontak antar sesama menjadi kurang, di satu sisi kawasan kedoya ini sendiri memiliki potensi yaitu banyaknya tanaman hias yang di perjual belikan dan dibudidayakan, tanaman - tanaman ini menjadi daya tarik tersendiri di kedoya sehingga diusulkan Proyek Fasilitas Rekreasi Interaktif Tanaman Hias menjadi tempat untuk dapat mewadahi kebutuhan warga setempat khususnya yang bersifat hiburan dan menjadi tempat bagi semua kalangan untuk bertemu dan saling berinteraksi dengan bermain bersama sekaligus menghidupkan identitas tanaman hias pada kawasan. Program proyek berupa ruang serba guna, gallery tanaman hias kering, instalasi tanaman hias, taman tanaman hias, area permainan papan dan meja, tempat makan yang terintegrasi dengan tanaman hias, dan taman virtual. Proses perancangan menggunakan metode fenomenologi dan konsep desain biofilik dengan mengambil 3 prinsip utamanya yaitu Nature In Space, Natural Analogue, dan Nature of Space dan menggunakan tanaman hias sebagai elemennya. Diharapkan proyek ini dapat menjadi titik simpul untuk bertemu dan berinteraksi tidak hanya dengan sesama namun juga dengan alam yang dapat berdampak positif bagi kesehatan, kenyamanan dan memberikan hiburan bagi warga Kedoya Utara.
\end{abstract}

Kata kunci: interaksi; interaktif; kedoya utara; rekreasi; tanaman hias

\begin{abstract}
Urban life especially Jakarta is inseparable from daily activities such as work, school, etc. Routines that are carried out repeatedly cause people to become bored and stressed which affects their performance, therefore it is important to have activities like entertainment to relieve fatigue, and stress. In North Kedoya interaction between neighbors is very lacking because of reluctance and feel strange, lack of joint activities and places to interact causing contact between people become less, on the other hand kedoya district has potential that many ornamental plants sold and traded and cultivated, these plants become a special attraction in the area so Interactive Ornamental Plants Facility Project proposed to be able to accommodate the needs of local residents, and become a place for all people to meet and interact with each other by playing together while reviving the identity of ornamental plants in the region. Project programs such as multipurpose room, gallery of ornamental plants, ornamental plant installations, ornamental plant gardens, board games and tables games, dining areas integrated with ornamental plants, and virtual park. The design process uses phenomenological methods and biophilic design concepts by using 3 biophilic main principles Nature In Space, Natural Analogue, and Nature Of Space and using ornamental plants as its elements. It is hoped that this project can become a node to meet and interact not only with others but also with nature which can have a positive impact on health, comfort and provide entertainment for the residents of North Kedoya.
\end{abstract}

Keywords: ornamental plants; interaction; interactive; north kedoya; recreation 


\section{PENDAHULUAN}

Kehidupan masyarakat tidak lepas dari rutinitas yang dilakukan setiap harinya yang terjadi pada lingkungan sosial yaitu di rumah yang merupakan first place dan tempat kerja yang merupakan second place, namun di dalam rutinitas tersebut dibutuhkan adanya third place yang merupakan tempat bagi masyarakat untuk beristirahat sejenak dari rutinitas tersebut. Perkembangan teknologi yang semakin maju membuat orang-orang lebih banyak menghabiskan waktunya menggunakan media sosial sehingga membuat orang-orang menjadi kurang berinteraksi di dunia nyata. Third place ini dibutuhkan untuk mewadahi kegiatan masyarakat yang bersifat netral, terbuka untuk setiap kalangan, playful dan dapat menjadi tempat interaksi sosial bagi masyarakat sekitar.

Kebutuhan akan adanya sarana rekreasi dan interaksi di lingkungan perkotaan dibutuhkan bagi masyarakat kota yang dipenuhi oleh rutinitas seperti bekerja, bersekolah, dan lain lain. Menurut hasil survey yang dilakukan oleh Bloom (2020) di dalam artikelnya pada website Forbes, dari 20 kota paling stress Jakarta menempati urutan ke 6 kota paling stress di dunia. Dilihat dari kehidupan keseharian masyarakat di kawasan Kedoya Utara setiap kalangan baik gender, umur, dan tingkat sosial melakukan kegiatan olahraga seperti senam dan bermain bola, bermain billiard, kartu, catur, bermain game, untuk mengisi waktu kosong dan melepas penat. Lokasi proyek yang berada di kawasan Kedoya Utara, jika dilihat dari fasilitas umum di kawasan tersebut, Kedoya Utara minim akan adanya sarana rekreasi, kalaupun ada hanya untuk kalangan tertentu dan berbayar sehingga hanya bersifat terbatas, hiburan adalah sarana yang bersifat universal dan dilakukan semua orang dengan begitu kegiatan ini dapat mewadahi interaksi sosial dan kebutuhan masyarakat di kawasan tersebut.

Kawasan didominasi oleh perumahan dan di dalam perumahan tersebut terdapat perkampungan padat namun yang menjadi permasalahan disini walaupun tempat tinggal yang berdekatan, interaksi antar warga sekitar masih minim, baik antar tetangga maupun antara yang tinggal di perkampungan maupun perumahan, hal ini mendorong akan adanya tempat yang bersifat netral dan universal yang dapat di jadikan sarana untuk berinteraksi dan rekreasi bagi semua golongan masyarakat sehingga dapat terjadi interaksi antar warga sekitar. Kawasan kedoya ini sendiri memiliki potensi yaitu banyaknya tanaman hias yang di perjual belikan di daerah perumahan di sisi lain tanaman-tanaman ini menjadi daya tarik tersendiri karena tanaman ini di tempatkan di median jalan dan menghiasi jalan tersebut sehingga pengguna jalan yang sering pulang pergi beraktivitas dapat melihat dan membeli tanaman hias tersebut. Tanaman yang terletak di dalam jalan perumahan menyebabkan tanaman tersebut kurang di ketahui oleh masyarakat umum di luar daerah sehingga dengan menjadikan tanaman hias sebagai sarana rekreasional yang interaktif dan juga komersil maka dapat lebih dikenal oleh masyarakat luas.

Proyek yang di usulkan berupa tempat rekreasi yang bertemakan tanaman hias yang memiliki aktivitas yang dominan bersifat hiburan dan tempat untuk berkumpul dan berinteraksi yang dapat digunakan oleh semua orang dari berbagai umur dan latar belakang, proses perancangan mempertimbangkan kebutuhan sehari-hari masyarakat dan potensi dari kawasan yaitu tanaman hias, karena berfokus pada orang itu sendiri maka konsep desain yang di ambil adalah biofilik yang berfokus hubungan manusia dengan alam untuk memberikan kenyamanan dan kesehatan baik fisik maupun mental, selain itu hiburan yang interaktif dapat mendorong interaksi antar sesama. 


\section{Rumusan Permasalahan}

Bagaimana rancangan atau desain dapat mewadahi kebutuhan akan sarana rekreasi dan menjadi wadah third place bagi warga setempat dengan ciri khas kawasan?

\section{Tujuan}

Merespon kebutuhan kawasan dan mendorong adanya interaksi sosial dengan adanya tempat rekreasi atau hiburan yang terbuka untuk umum dengan tanaman hias sebagai salah satu medianya, mendekatkan manusia dengan alam dan agar orang mengerti pentingnya alam serta meningkatkan kualitas psikologi dan fisik manusia.

\section{KAJIAN LITERATUR}

\section{Open Architecture}

Open Architecture adalah Third place yang dimana merupakan tempat untuk mempertemukan berbagai macam masyarakat dimana merupakan kegiatan yang tidak terkait dengan rutinitas rumah (first place) dan rutinitas pekerjaan (second place), third place diperlukan bagi semua orang karena merupakan tempat agar orang dapat melepas penat akibat dari aktivitas keseharian mereka. Terdapat 7 karakter third place menurut Oldenburg (1997) di dalam bukunya The Great Good Place:

a. Third place merupakan tempat yang Netral

Setiap individu yang pergi ke third place memiliki kedudukan yang sama dan tidak ada hirarki maupun status sehingga dapat diterima oleh semua orang.

b. Hilangnya tingkat perbedaan antar manusia

Didalam third place ini merupakan tempat berkumpulnya berbagai macam karakter manusia, namun di dalam third place hal tersebut dihilangkan.

c. Third place sebagai tempat pertemuan didominasi dengan aktivitas perbincangan.

Mengobrol adalah aktivitas yang signifikan, topik yang diperbincangan bermacam-macam. Orang-orang dapat bebas berekspresi, dan berbagi ide dan pengalaman dengan orang lain.

d. Pengunjung third place adalah pengunjung regular

Third place merupakan bagian dari komunitas suatu tempat atau area (district). Kedekatan antar pengunjung merupakan hal terpenting dalam pembentukkan third place, dan terdapat pengunjung regular yang menghidupi third place tersebut.

e. Aksebilitas

Aksebilitas sangat diperlukan, third place mudah dicapai, tidak terbatas maupun terkekang.

f. Third place menjadi tempat netral, dan sederhana (unpretentious).

Kesederhanaan dibutuhkan agar masyarakat dapat datang tanpa keraguan. Terkadang dalam pembentukkannya arsitektur menggunakan symbol - symbol tertentu, yang menimbulkan interpretasi bagi masyarakat tertentu, karena interpretasi ini maka timbul segregasi dan keenganan untuk datang ke bangunan tertentu. Dengan adanya kesederhanaan ini dapat membuat Third place terbuka bagi siapa saja.

g. Third place, tempat ini haruslah playful atau menyenangkan bagi siapapun

Third place mempengaruhi emosi individu sehingga saat meninggalkan tempat tersebut orang merasa senang dan gembira. Third place disini tidak hanya menjadi tempat bagi masyarakat untuk berkumpul melainkan dapat menjadi tempat dimana masyarakat dapat menemukan kegembiraan didalam kebersamaan.

Sebuah third place perlu terbuka bagi siapa saja dari berbagai macam latar belakang seperti umur, pekerjaan, status, dan lain lain. Third place sebagai tempat yang mampu memenuhi kebutuhan kota yang mampu berfungsi secara fleksibel dan juga dinamis sesuai kebutuhan masyarakatnya. 


\section{Kebutuhan Dasar Manusia}

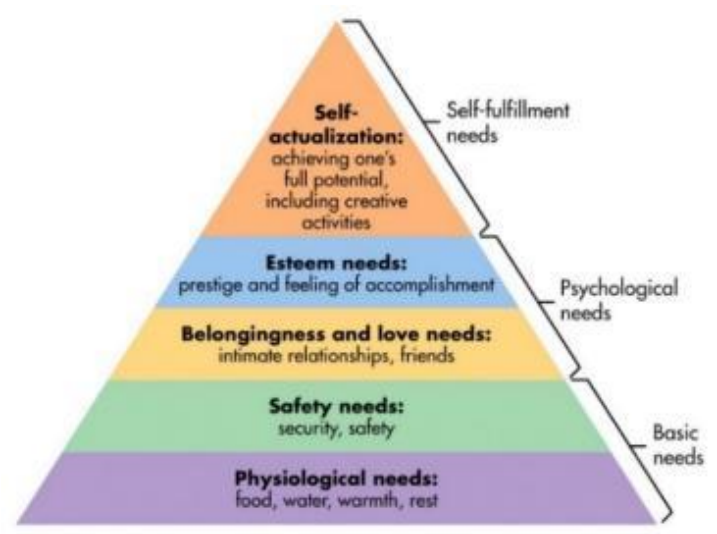

Gambar 1. Hirarki Kebutuhan Manusia Abraham Maslow Sumber: simplypsychology.org, 2020

Dari teori Human Needs oleh Abraham Maslow manusia mempunyai kebutuhan - kebutuhan hidup yang harus di penuhi, dan kebutuhan - kebutuhan tersebut memiliki tingkatan seperti yang dapat dilihat dari piramida kebutuhan manusia. Melihat manusia sebagai pusat dari kehidupan kota adaptasi dari hirarki ini pada bidang arsitektur diperlukan sehingga pendekatan desain lebih manusiawi dan dapat memenuhi kebutuhan warga setempat.

\section{Biofilik}

Pendekatan ini mirip dengan konsep "green" namun yang berbeda disini adalah desain yang menghadirkan ruang hijau untuk meningkatkan kualitas hidup baik itu kesehatan, kesejahteraan fisik maupun psikologis manusia, konsep ini mencoba mere-koneksi kembali manusia dengan alam sebagaimana kasusnya pada masyarakat modern yang sudah jauh dengan alam. Konsep biofilik ini bukan serta merta hanya tanaman saja namun juga aspek alam lain seperti udara, cahaya, dan lain - lain. Menurut Browning (2014) dalam buku 14 Patterns of Biophilic Design terdapat 3 prinsip utama yaitu:

a. Nature in The Space

Hubungan non-visual dengan alam, koneksi singkat dengan alam, pengaturan tempratur dan aliran udara di dalam ruang/bangunan, unsur air di dalam desain, pengaturan cahaya, dan hubungan bangunan dengan sistem alam.

b. Natural Analogues

Unsur - unsur alam diadaptasi ke dalam bentuk - bentuk analogi di dalam desain, penerapannya seperti bentuk biomorfik, kompleksitas tatanan bentuk ornamen dalam tampilan bangunan, dan penggunaan material - material alam.

c. Nature of The Space

Menerangkan kualitas ruang dimana di dalam sebuah ruang, pengguna dapat merasakan seperti berada di alam. Prinsip ini meliputi prospek yaitu sebuah kesan pemandangan yang leluasa, refuge perasaan terlindungi dari gangguan, misteri yaitu keterbatasan informasi yang diberikan dengan jelas, guna menarik rasa ingin tahu dari pengguna.

\section{Tanaman Hias}

Tanaman hias memiliki peran dalam meningkatkan kenyamanan hidup serta menciptakan lingkungan yang bersih dan segar, kondisi tersebut merupakan kebutuhan terutama bagi masyarakat yang tinggal di daerah perkotaan yang sangat padat dengan berbagai polusi, tanaman hias dapat memberikan pengaruh positif terhadap upaya mengurangi kepenatan, memberikan rasa segar pada indra dan memberikan nilai tambah perekonomian keluarga (Mursito \& Prihmantoro, 2011). Berdasarkan penjelasan tersebut tanaman hias bukan hanya 
sekedar elemen dekorasi tetapi jika diteliti lebih lanjut tanaman hias juga dapat digunakan untuk hal lain salah satunya sebagai hiburan, selain itu menurut Mursito (2011) diantara tanaman hias tersebut ternyata ada yang memiliki khasiat untuk di jadikan obat maupun herbal, setiap tanaman memiliki khasiatnya masing - masing karena kandungan di dalamnya berbeda. Wangi harum dari beberapa jenis tanaman hias dapat memberikan pengalaman ruang yang berbeda pernyataan ini diperkuat dengan pernyataan Evanindya (2011) di dalam skripsinya yang berjudul "Aroma Dalam Ruang Arsitektur" yaitu "walaupun tidak kasat mata keberadaan suatu aroma dapat menciptakan sebuah situasi dimana manusia menyadari adanya sebuah ruang".

\section{METODE}

Metode perancangan yang digunakan dalam perancangan :

Tahap pengumpulan data:

a. Studi Literatur

Literatur di ambil dari Browning (2014), Mursito (2011), Oldenburg (1997), yaitu sebagai dasar teoritis dasar pemikiran; mengetahui tentang tanaman hias; mengetahui dan standar third place

b. Studi Preseden

Preseden yang di pakai Fuji Kindergarten, Tujuhari Coffee, Taoyuanju Community Center; sebagai pembanding dan gambaran proyek

\section{Metode pengamatan}

Metode dilakukan dengan survey lapangan, wawancara, dan dokumentasi lapangan

\section{Metode penelitian dan perancangan}

Metode dilakukan dengan analisa tapak dan lingkungan; program didapat dari hasil analisa kegiatan sehari - hari dan kebutuhan warga setempat; Pengolahan data dari hasil analisa dan studi literatur untuk perancangan. Metode penelitian menggunakan metode fenomenologi, menurut Tjahjono (2000) prinsip metode ini adalah kembali pada benda - benda (yang diamati) itu sendiri, penekanan metode ini pada persepsi, kognisi, dan pengalaman individual.

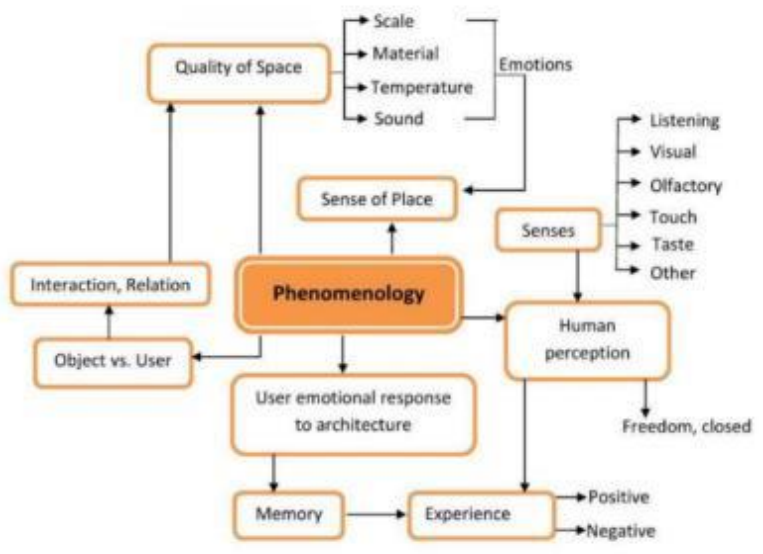

Gambar 2. Diagram Metode Fenomenologi

Sumber: Issuu.com, 2016

Metode ini digunakan untuk melihat fenomena yang ada seperti dilihat dari kehidupan keseharian warga di kawasan Kedoya, didapatkan bahwa adanya kebutuhan manusia akan hiburan dan berinteraksi karena pada dasarnya manusia adalah makhluk sosial, lalu didapati masalah yaitu terjadi kurangnya interaksi antara warga setempat khususnya antara yang tinggal di perumahan dan yang tinggal di perkampungan. 


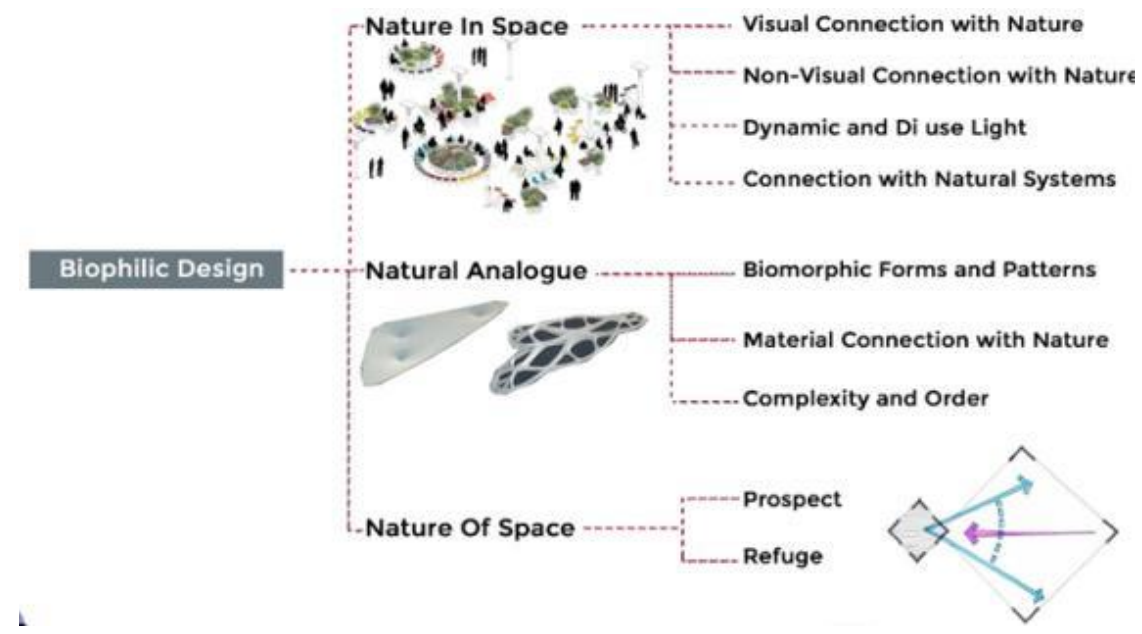

Gambar 3. Diagram Metode Perancangan Biofilik

Sumber: Browning, 2014

Melihat fenomena dimana pada dasarnya manusia memiliki kecenderungan bawaan untuk berhubungan dengan alam diperkuat dengan pernyataan oleh Kellert (2015) di dalam bukunya "The Practice of Biophilic Design" manusia adalah makhluk yang menyukai alam dam dan berada pada kemampuan optimalnya ketika berada di lingkungan alami, dalam kasus ini dilihat dari potensi kawasan yang dimana terdapat banyak yang menjual tanaman hias dan di tempat tinggal warga banyak yang menggunakan tanaman hias sebagai elemen di rumahnya sehingga di angkat tema "Tanaman Hias". Untuk memperkuat tema tersebut dan penggunaan tanaman lebih optimal maka metode perancangan yang digunakan adalah metode perancangan biofilik pada diagram di atas.

\section{DISKUSI DAN HASIL}

Sebelum masuk ke tahap desain dilakukan tahap pendataan dan analisa terhadap lingkungan yang kemudian akan mempengaruhi bentuk bangunan.

\section{Tapak}

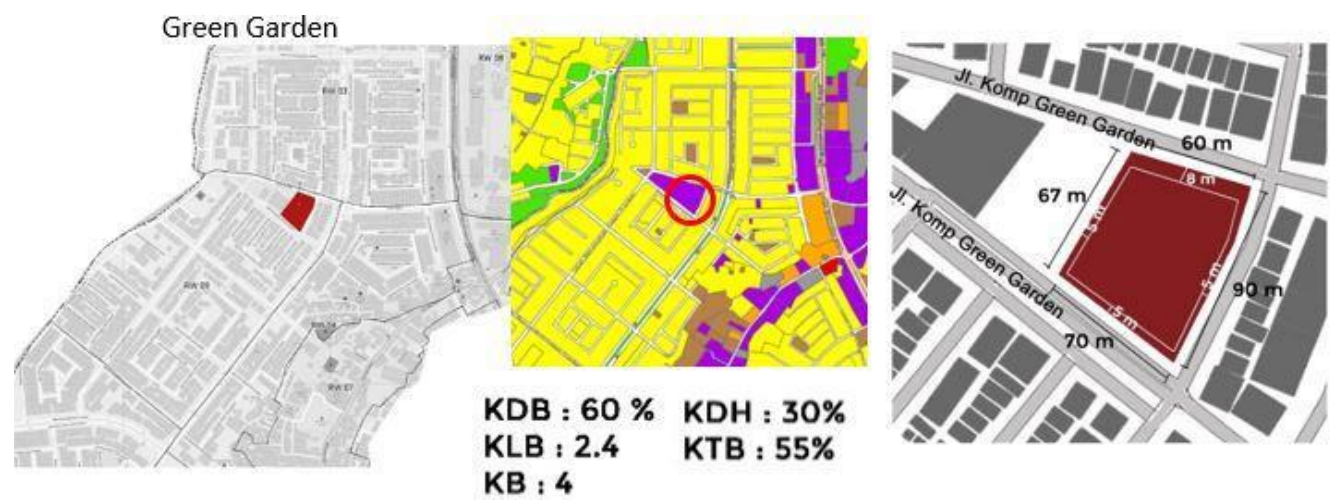

Gambar 3. Data dan Lokasi Tapak

Sumber: Data Pribadi dan Jakartasatu, 2020

Tapak berada di Kecamatan Kebun Jeruk, kelurahan Kedoya Utara di dalam komplek perumahan Green Garden. Letak tapak mudah di akses bagi warga setempat dan orang dari luar lingkungan. 

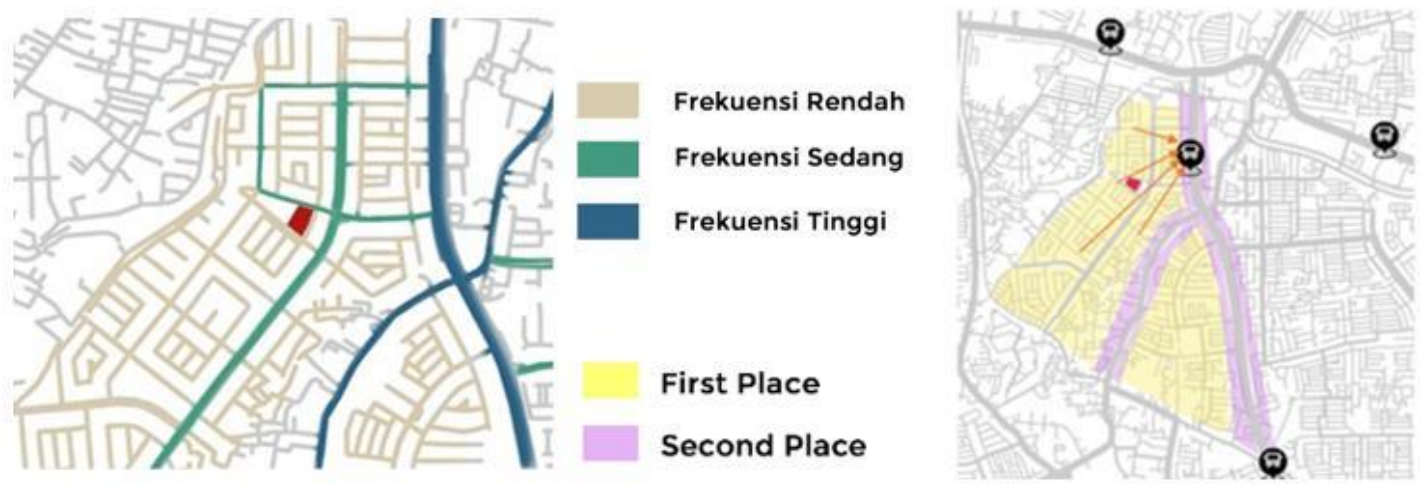

Gambar 4. Data Tapak

Sumber: Data Pribadi dan Jakartasatu, 2020

Tapak berada di jalan frekuensi sedang yang di pengaruhi letak transpportasi umum dan letak first place dan second place sehingga tapak memiliki potensi untuk dijadikan titik simpul, tempat rekeasional bagi masyarakat setempat, dan tempat pemberhentian sementara.

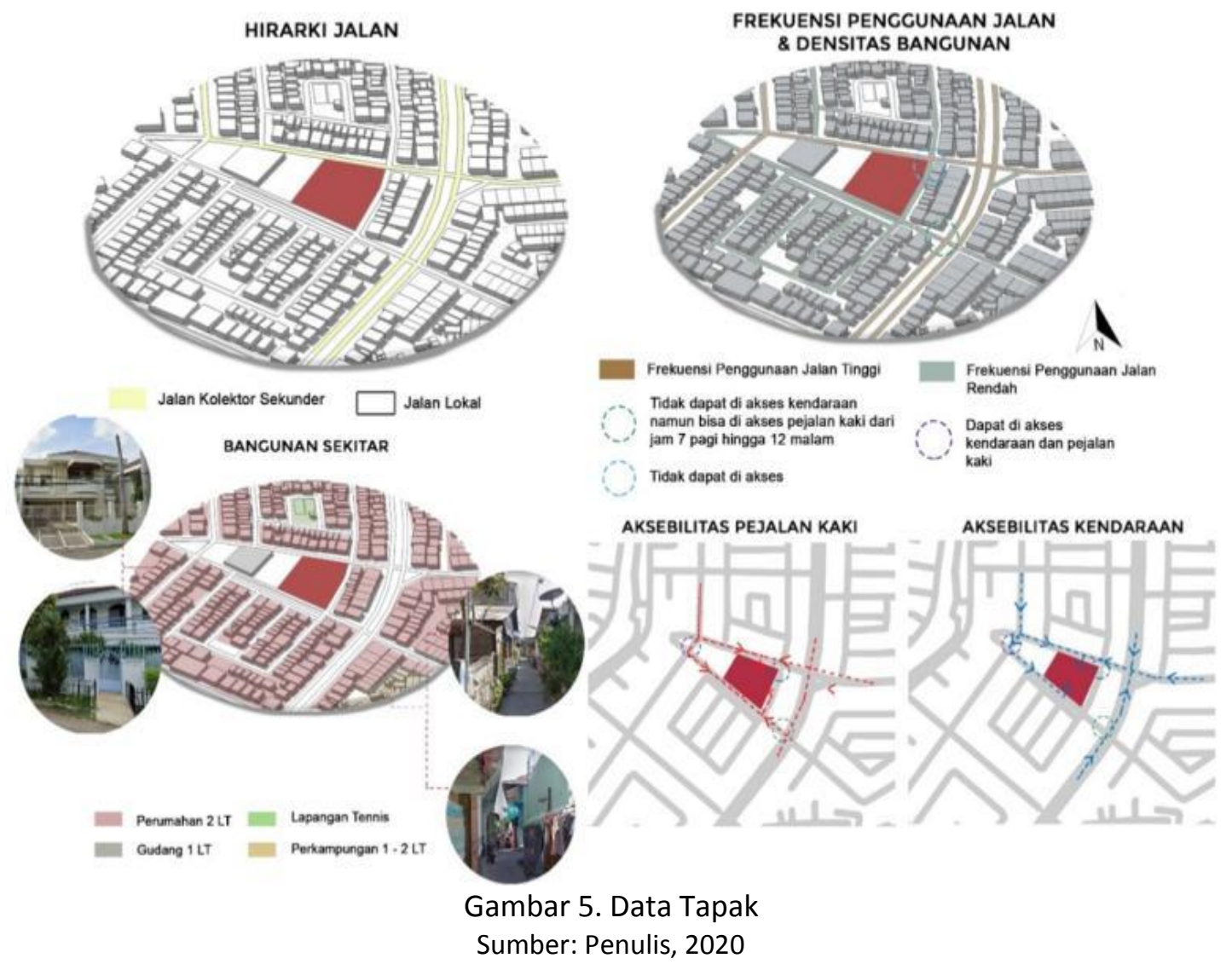

Berdasarkan data diatas, posisi tapak berpotensi menjadi titik simpul di kawasan karena letak yang berada di jalan umum dengan frekuensi penggunaan tinggi yang dipengaruhi letak tempat tinggal dan tempat kerja, selain itu karena beberapa titik akses yang hanya bisa diakses terbatas maka hal ini mempengaruhi posisi arah masuk utama dan jam operasional bangunan. Tidak adanya view yang menonjol pada area sekitar karena dikelilingi perumahan maka dengan membuat area terbuka terbuka dan area hijau yang besar dapat menjadi daya tarik sendiri pada projek. 


\section{Potensi Kawasan}
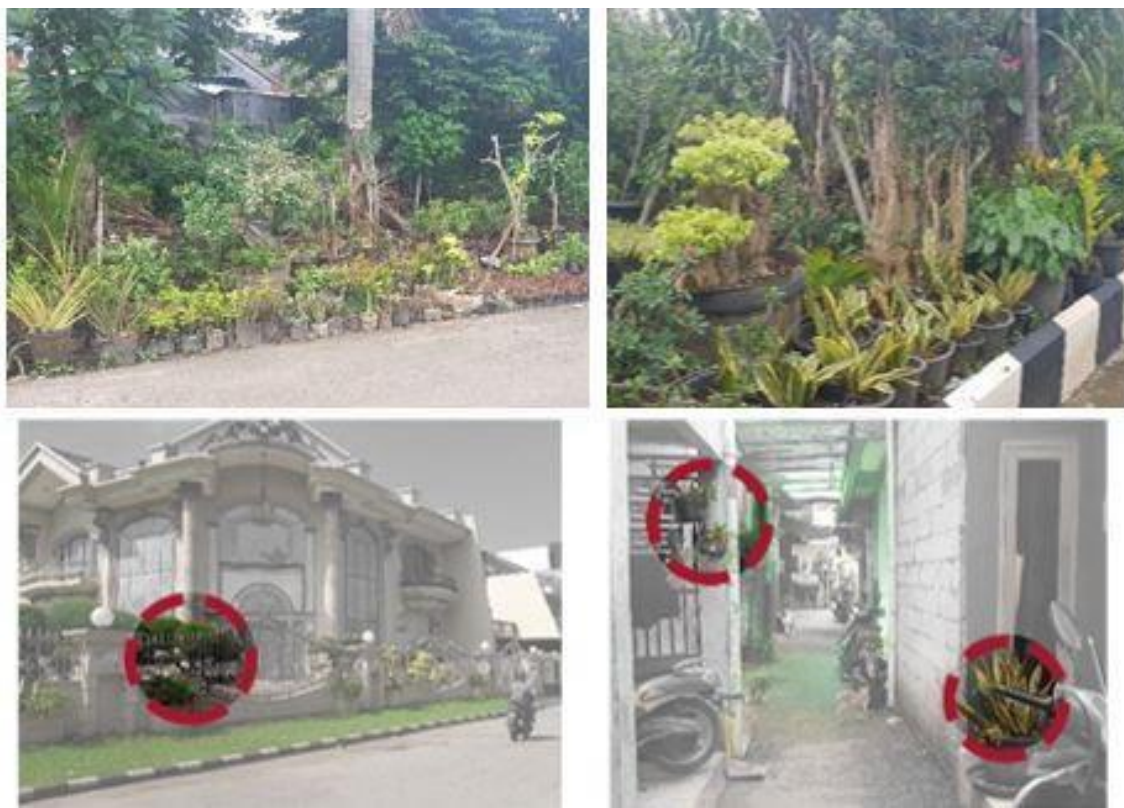

Gambar 6. Tanaman Hias Pada Median Jalan dan Tempat Tinggal

Sumber: Penulis, 2020

Kawasan Kedoya Utara berpotensi akan tanaman hiasnya, tanaman hias ini dapat berpotensi sebagai citra kawasan Kedoya Utara. Banyak warga yang menjual dan membudidayakan tanaman hias dan baik orang yang tinggal di dalam perkampungan maupun yang di perumahan memiliki tanaman hias di tempat tinggalnya, hal ini menunjukkan kecenderungan manusia untuk dekat dengan alam maka tanaman hias dijadikan tema dalam proyek ini.

\section{Program}

Program didapatkan berdasarkan metode penelitian fenomenologi dengan melihat kegiatan sehari-hari masyarakat, kemudian didapati kegiatan netral yang di lakukan semua org dari berbagai umur dan latar belakang yaitu kegiatan yang bersifat rekreasional, kemudian berdasarkan tema yang di angkat maka tanaman hias dijadikan salah satu program utama yang menjadi sarana hiburan interaktif.

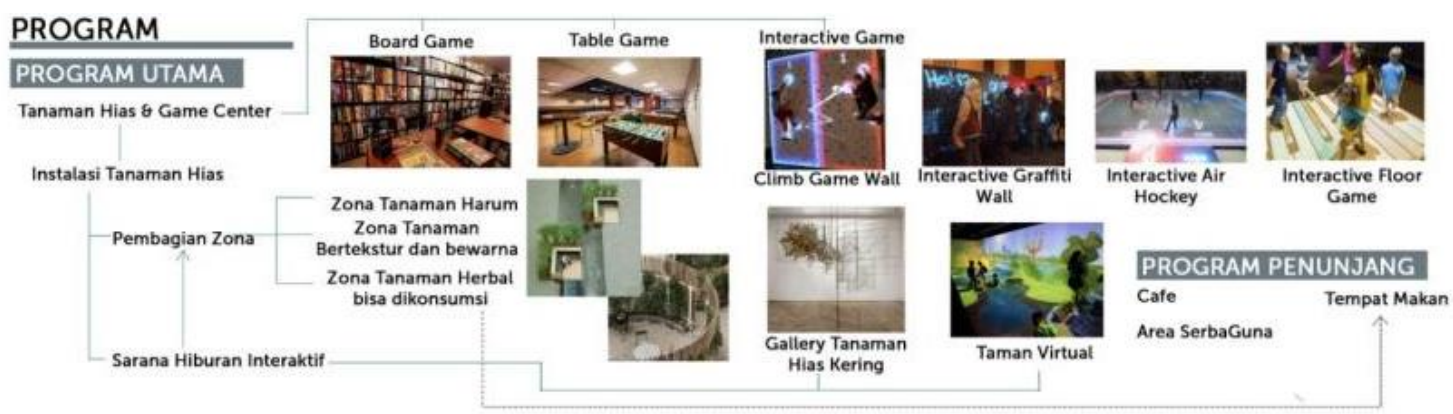

Gambar 7. Diagram Program

Sumber: Penulis, 2020 


\section{Proses Gubah Massa}

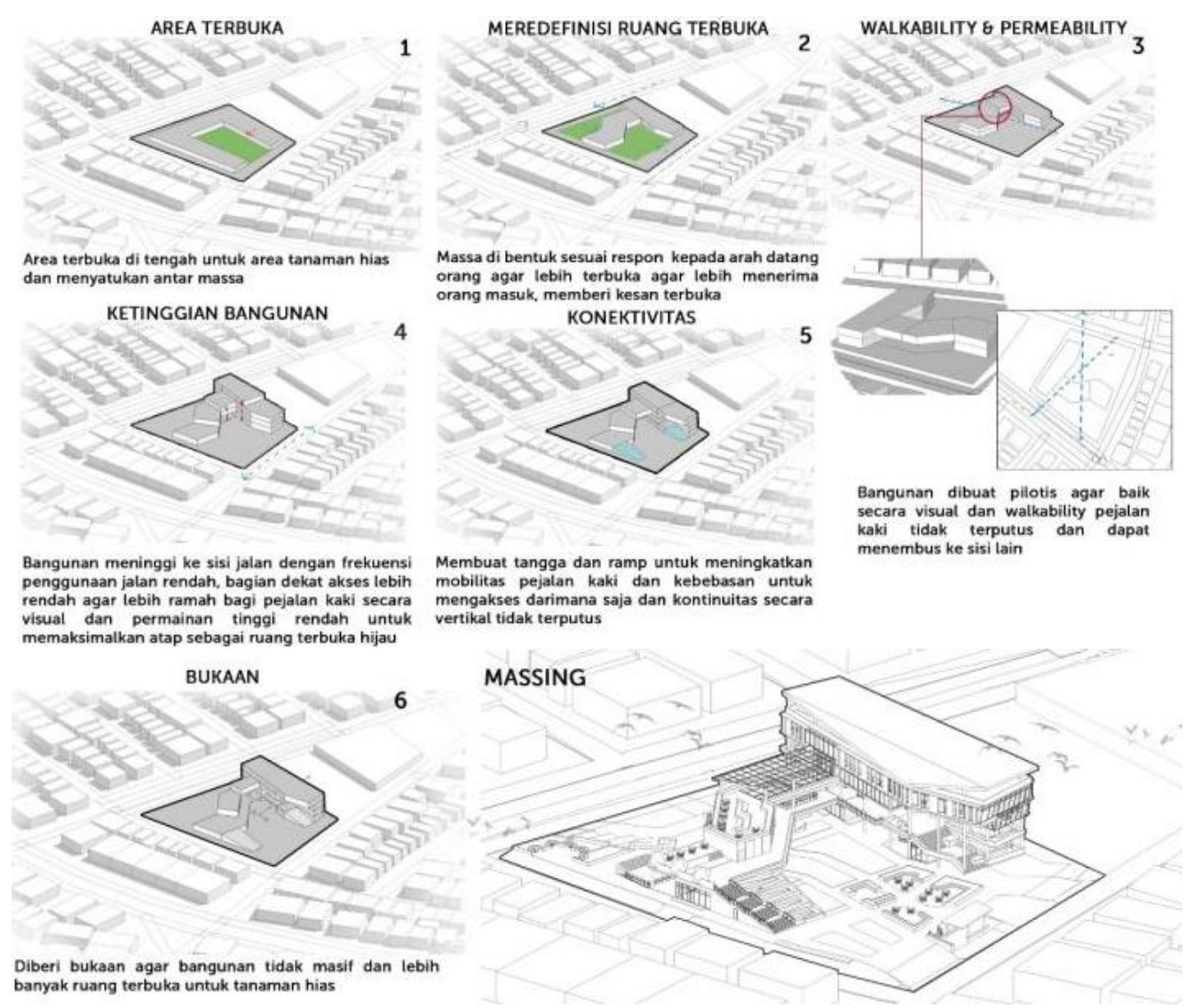

Gambar 8. Proses Gubah Massa dan Massing

Sumber: Penulis, 2020

Bentuk massa bangunan disesuaikan sebagai respon dari data tapak yang kemudian dianalisa agar bangunan kontekstual dengan kondisi lingkungan, tidak menghalangi cahaya dan dapat menjadi daya tarik dan tempat yang terbuka bagi semua orang.

\section{Konsep}

Desain dirancang berdasarkan studi literatur dan analisa tapak, dan memadukan dengan tema yang diangkat yaitu "tanaman hias" maka konsep yang di pakai adalah konsep biofilik yaitu konsep yang mirip dengan konsep "hijau" namun lebih menekankan pada manusia agar kenyamanan dan kesehatan baik fisik maupun mental penggunanya. Konsep ini terintegrasi dengan metode fenomenologi dimana penerapan konsep ini dapat mempengaruhi persepsi orang, dan sense of place yang berdampak pada emosi orang agar merasa lebih bebas, terbuka, dan playful, sehingga tujuan projek sebagai tempat yang bersifat rekreasional dapat tercapai. Konsep desain mengacu pada 3 prinsip utama biofilik yaitu Nature in Space, Natural Analogue, dan Nature of Space, ketiga prinsip ini di pakai agar kesan alam dapat lebih dominan dan memberikan dampak bagi penggunanya sehingga bisa menjadi objek rekreasional yang memenuhi kebutuhan penggunanya. 


\section{NATURE IN SPACE}
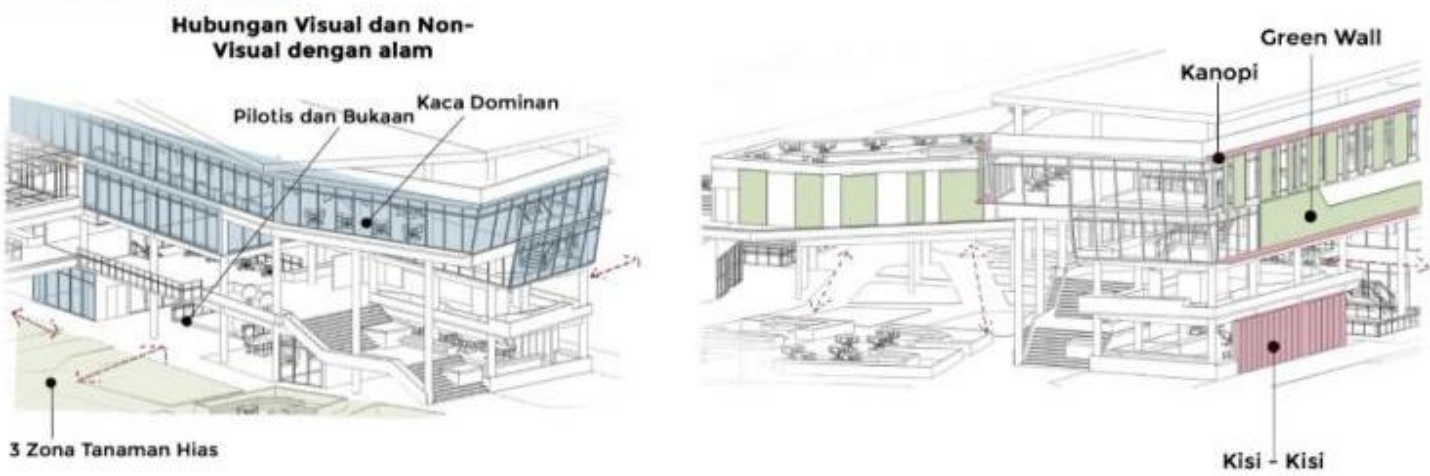

Gambar 9. Prinsip Nature in Space

Sumber: Penulis, 2020

Lantai dasar pilotis, banyak bukaan dan penggunaan kaca yang dominan agar memberikan hubungan visual dengan alam, dan juga dengan adanya bukaan terjadi ventilasi udara alami. Pengaturan cahaya dengan menggunakan green wall, kanopi dan kisi-kisi agar Cahaya yang masuk tidak berlebihan.

\section{NATURAL ANALOGUE}

Penerapan Bentuk Alam pada bangunan.

ornamen - ornamen, dan Material - Material Alam
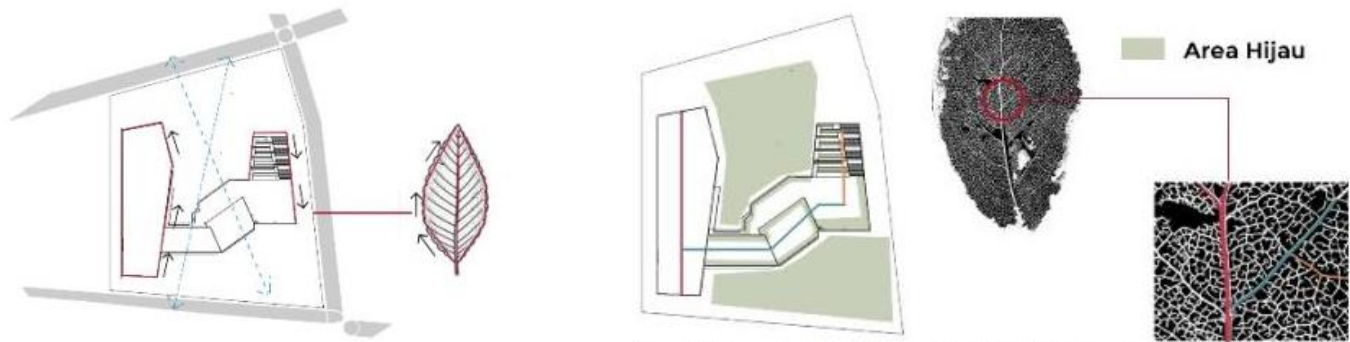

Gambar 10. Prinsip Natural Analogue

Sumber: Penulis, 2020

Bentuk massa mengikuti bentuk geometris dari daun yang membesar kebagian tengah kemudian mengecil di ujung selain itu juga agar tidak menganggu secara visual. Susunan massa mengikuti struktur tulang daun yang bercabang namun satu kesatuan dan berkesinambungan, hal ini juga tercerminkan pada ruang hijau yang tidak terputus dari lantai dasar ke lantai-lantai lainnya.

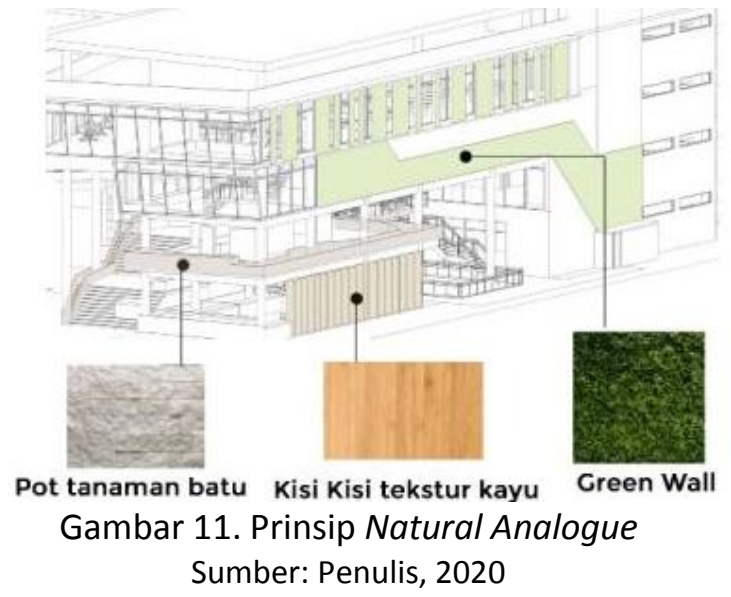


Penggunaan material dan tekstur alam pada bangunan baik di dalam ruang maupun pada fasad bangunan, selain itu menggunakan warna-warna natural pada ruang-ruang sehingga memperkuat kesan alami.

\section{NATURE OF SPACE}

Prospect, Refuge, Mystery

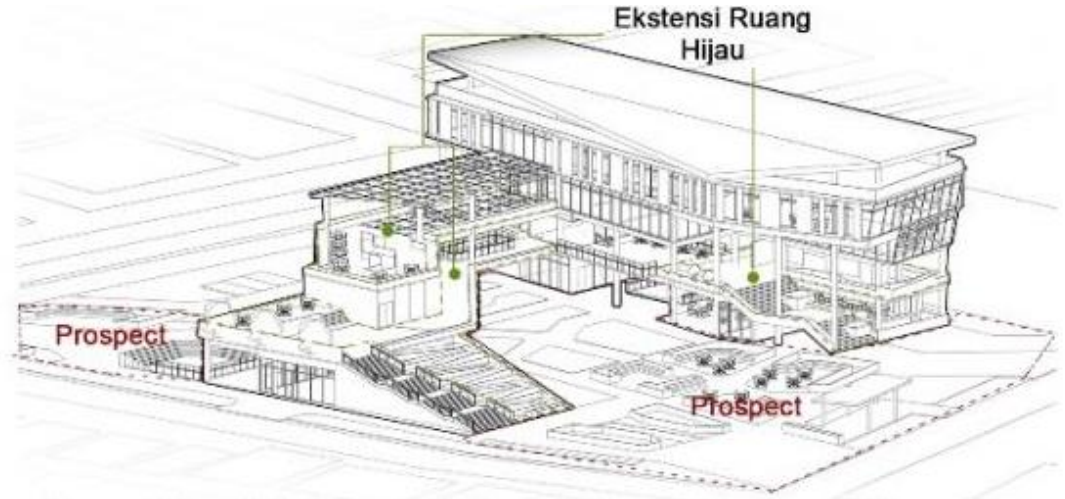

Gambar 12. Prinsip Nature Of Space

Sumber: Penulis, 2020

Prinsip yang menekankan kualitas ruang, sehingga orang dapat merasakan perasaan ketika berada di alam ruang hijau tidak hanya di lantai dasar saja namun diperluas ke lantai - lantai di atasnya menjadi roof garden dan fasad bangunan sehingga pengalaman ruang hijau lebih optimal. Prospect, menciptakan pandangan seluas - luasnya terhadap alam dari sebuah ruang. Refuge adalah uang yang menciptakan rasa aman bagi manusia

\section{Zoning}

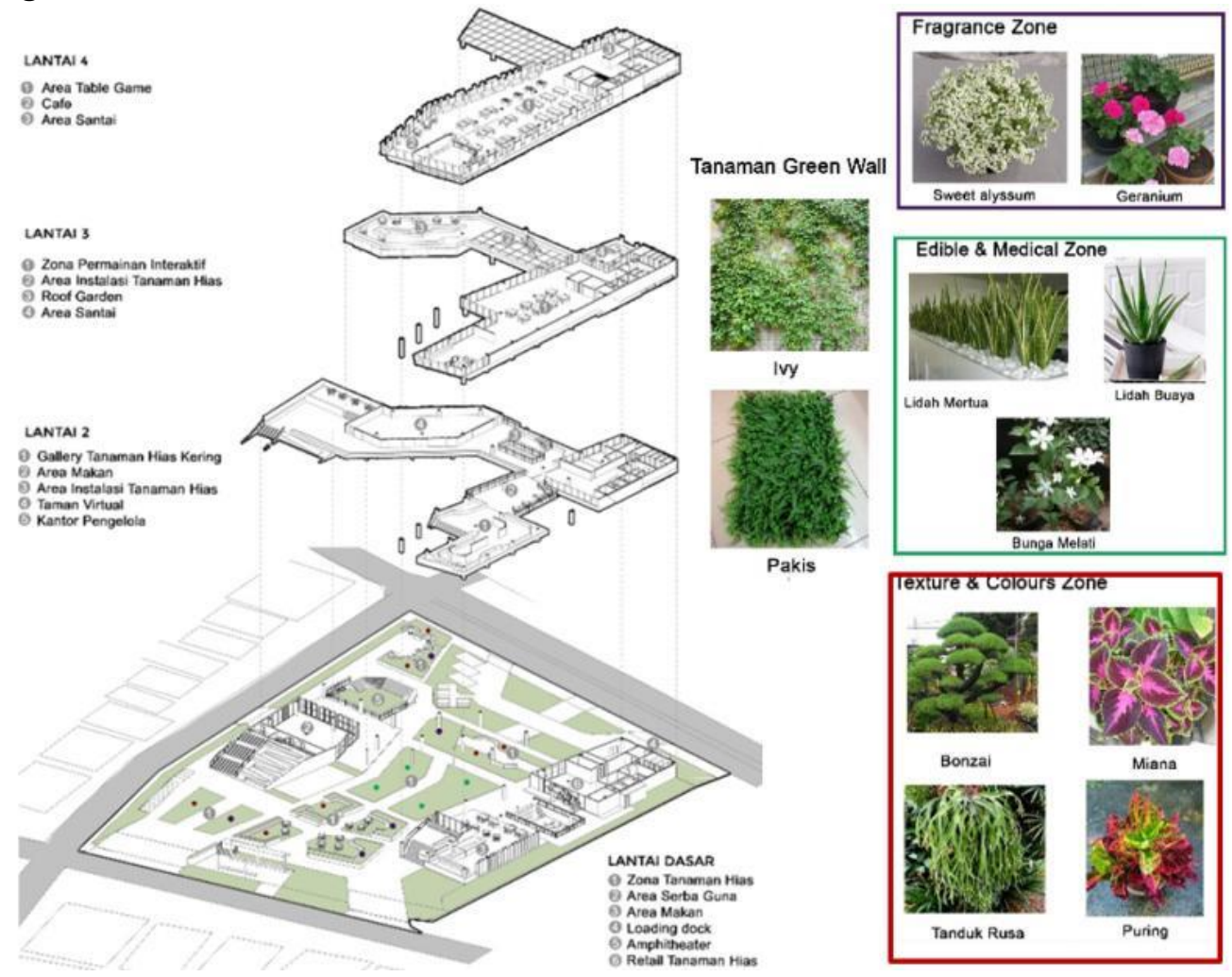

Gambar 13. Zoning dan Klasifikasi Tanaman Hias Sumber: Penulis, 2020 
Pada lantai dasar lebih dominan ruang terbuka hijau dan difungsikan untuk hiburan dan komersil, Zona tanaman hias terdapat area duduk yang di kelilingi tanaman yang membentuk suatu ruang imajiner yang memberikan kenyamanan bagi manusia. Pembagian zona tanaman hias ini agar orang dapat mengeksplorasi dan merasakan tanaman dari berbagai macam indra sehingga timbul interaksi antara manusia dan tanaman yang mempengaruhi quality of space berdasarkan metode fenomenologi. Pemilihan jenis-jenis tanaman hias ini berdasarkan tanaman yang dibudidayakan oleh warga setempat di kedoya utara ini.

Orang dapat berinteraksi dengan tanaman hias melalui 3 macam model yaitu:

a. Langsung

Orang dapat memetik langsung tanaman hias herbal sesuai arahan kemudian dapat membawanya ke tempat makan dan kemudian di olah menjadi makanan maupun minuman herbal, selain itu orang dapat berswafoto maupun melakukan kegiatan seperti merangkai tanaman.

b. Tidak langsung

Pemandangan ruang terbuka hijau yang dominan dan area duduk dan bermain outdoor yang dikelilingi tanaman hias dapat mempengaruhi persepsi, emosi dan sense of place seseorang ini dapat memberikan kenyamanan bagi setiap individu untuk saling berinteraksi.

c. Simbolik

Taman virtual yang memberikan gambaran alam bukan hanya sebagai sarana hiburan saja namun sebagai sarana untuk orang belajar lebih banyak tentang tanaman yang mendorong perilaku untuk dekat dengan alam.

\section{Nature Interaction Model}

\section{Direct}

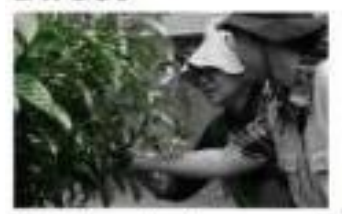

Berjalan di alam, memetik/berinteraksi langsung dengan tanaman, bermain di latar hijau

\section{Indirect}

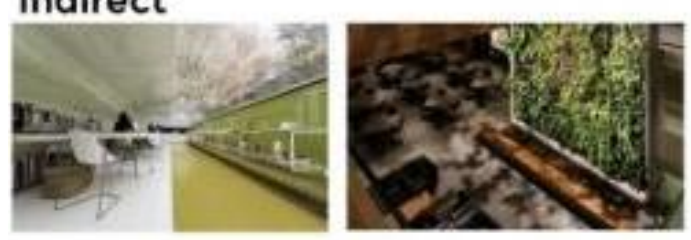

Alam Sekitar, View ke alam, Suasana ruang

\section{Symbolic}

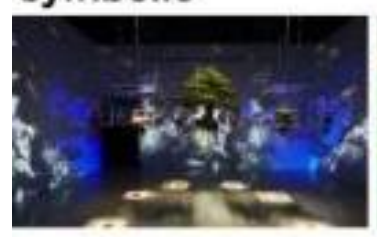

Gambaran / setting alam

\section{Manfaat}

Meningkatkan kognitif

Meningkatkan preferensi bermain di outdoor

Memahami kompleksitas alami dalam ruang

\section{Buffer untuk stress}

Meningkatkan kinerja, dan memberikan rasa nyaman dan ramah

\author{
Mendorong perilaku \\ ekologis \\ Meningkatkan kognitif \\ Buffer untuk stress
}

Gambar 14. Model Interaksi Alam

Sumber: Holtman, 2020 


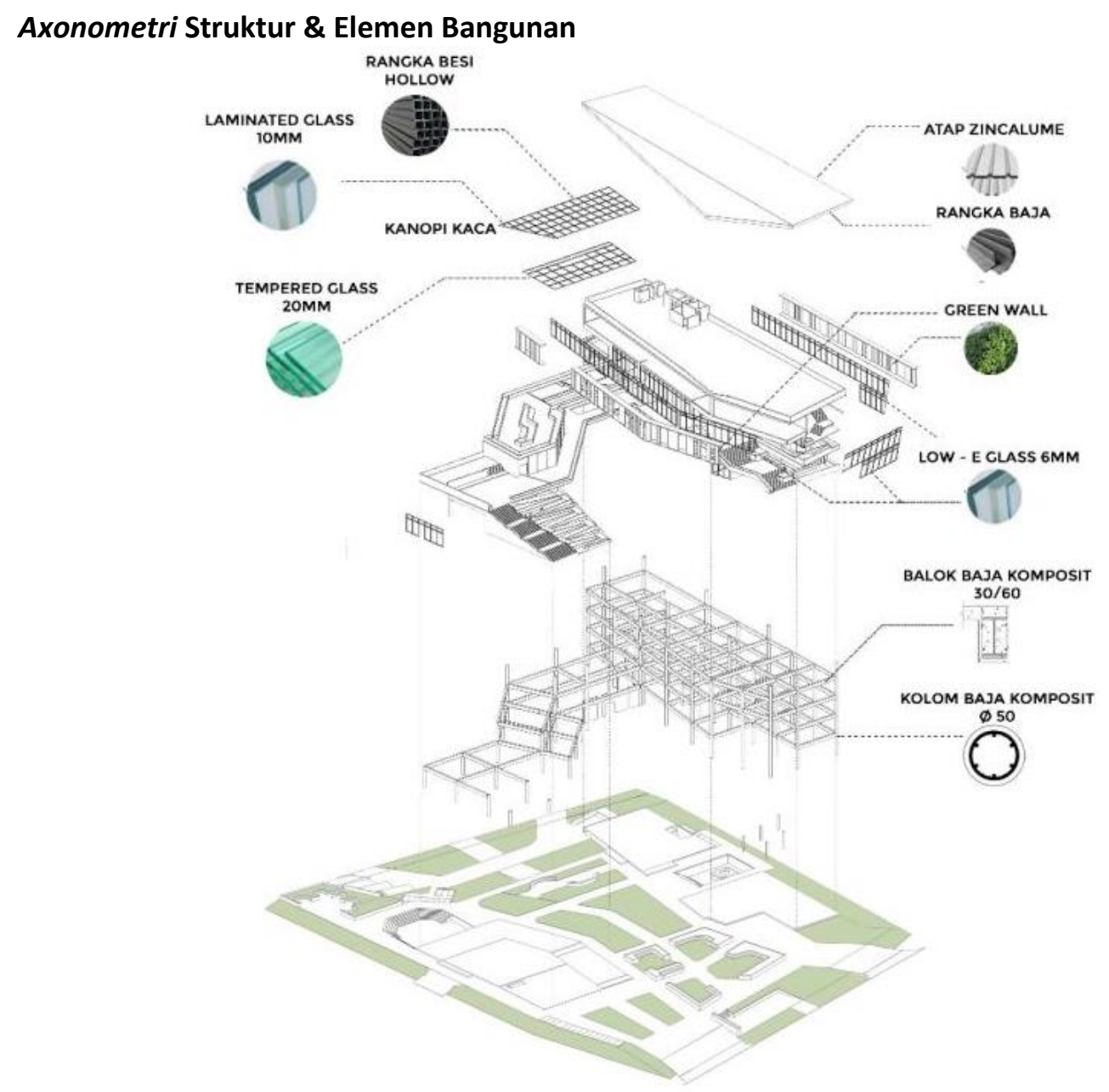

Gambar 15. Axonometri Struktur dan Elemen Bangunan Sumber: Penulis, 2020

Struktur yang digunakan adalah kolom bulat baja komposit diameter 50 dan balok baja komposit 30/60 lalu untuk kaca menggunakan kaca low-e utk curtain wall dan lantai kaca tempered $20 \mathrm{~mm}$ dan kanopi kaca laminated glass $10 \mathrm{~mm}$ yang menggunakan struktur rangka hollow, lalu atap menggunakan rangka baja dan penutup atap zincalume. Penggunaan elemen kaca pada area instalasi tanaman hias bertujuan agar masuknya cahaya alami untuk menunjang kelangsungan hidup tanaman pada area instalasi tanaman hias.

\section{Perspektif}

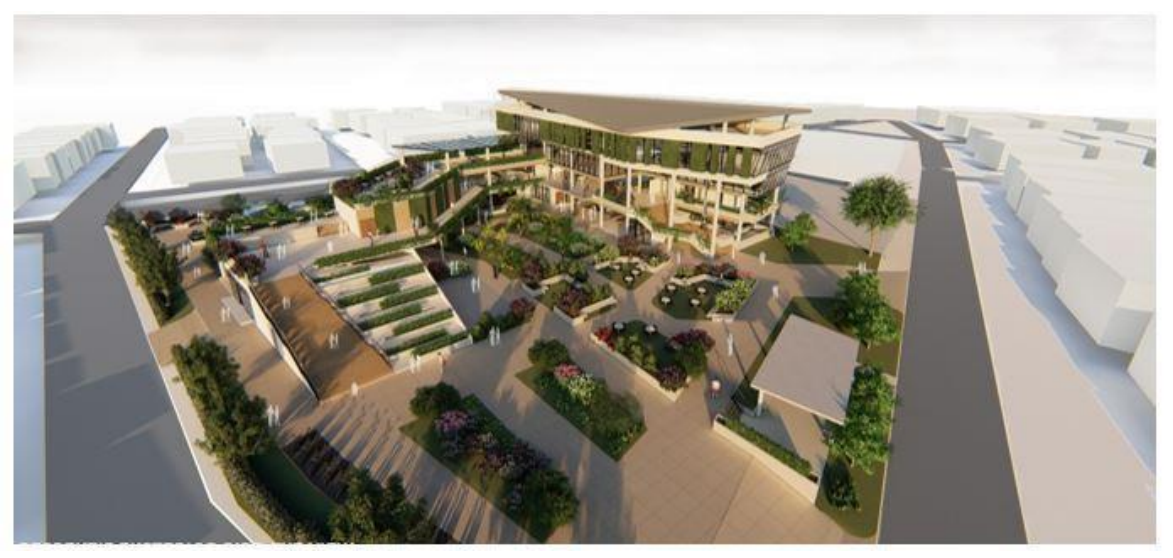




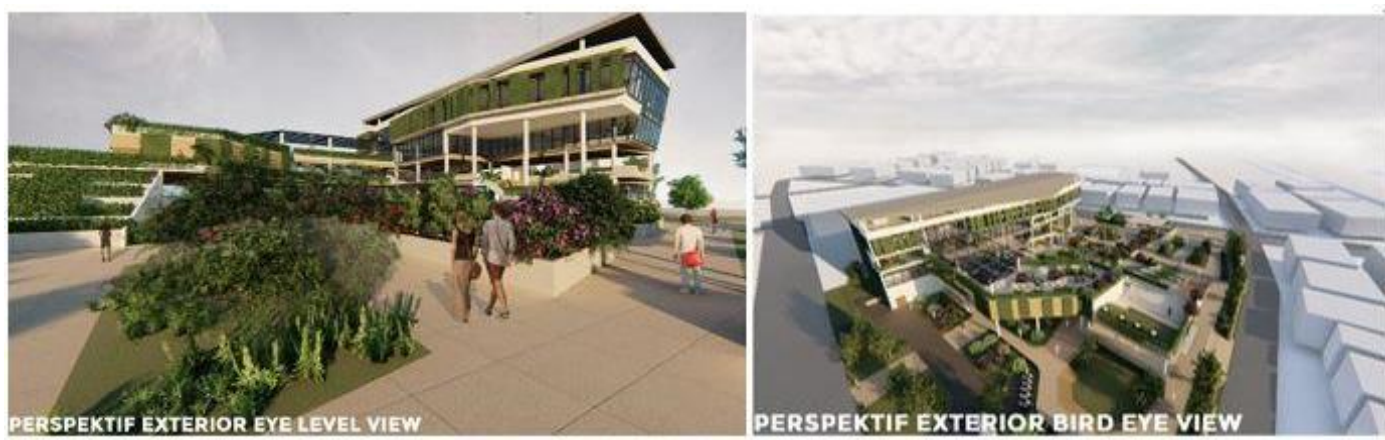

Gambar 16. Perspektif Eksterior

Sumber: Penulis, 2020

Massa bangunan dibuat tidak masif dan lebih terbuka agar cahaya dapat mengenai tanaman dan lebih memberikan kesan menerima untuk semua orang, selain itu tanaman tidak hanya dominan pada lantai dasar saja namun juga ke bangunan agar kesan alam dapat terwujud dan juga secara fungsional dapat menjadi buffer cahaya dan panas agar memberikan kenyamanan bagi penggunanya sesuai pola konsep biofilik oleh Browning (2014) didalam bukunya "14 Patterns of Biophilic Design". Area terbuka dan bebas memberikan ruang bagi orang untuk berkumpul dan berinteraksi bersama serta menghilangkan kesan ekslusif dan menonjolkan kesan terbuka dan tempat rekreasi, hal ini bertujuan untuk mencapai karakteristik dari third place oleh Oldenburg (1997) di dalam bukunya "The Great Good Place" yakni "netral", "sederhana", "hilangnya tingkat perbedaan", dan "aksesbilitas". Tanaman hias dijadikan media hiburan dan elemen penting dalam desain, disini konsep biofilik dan konsep third place saling menunjang satu sama lain, selain itu untuk mendukung kenyamanan bagi penggunanya diterapkan konsep prinsip biofilik yaitu seperti penggunaan material dan warna - warna alami seperti warna coklat kayu, hijau daun tidak hanya pada luar bangunan namun juga dalam perancangan ruang dalam. Tidak hanya pada bentuk namun dari program aktivitas banyak area-area duduk dan bersantai pada lantai dasar yang dapat digunakan untuk berkumpul, mengobrol, maupun bermain permainan papan seperti catur maupun kartu, kegiatan ini sesuai dengan karakteristik Third place yaitu "aktivitas didominasi dengan aktivitas berbincang", dan "playful".
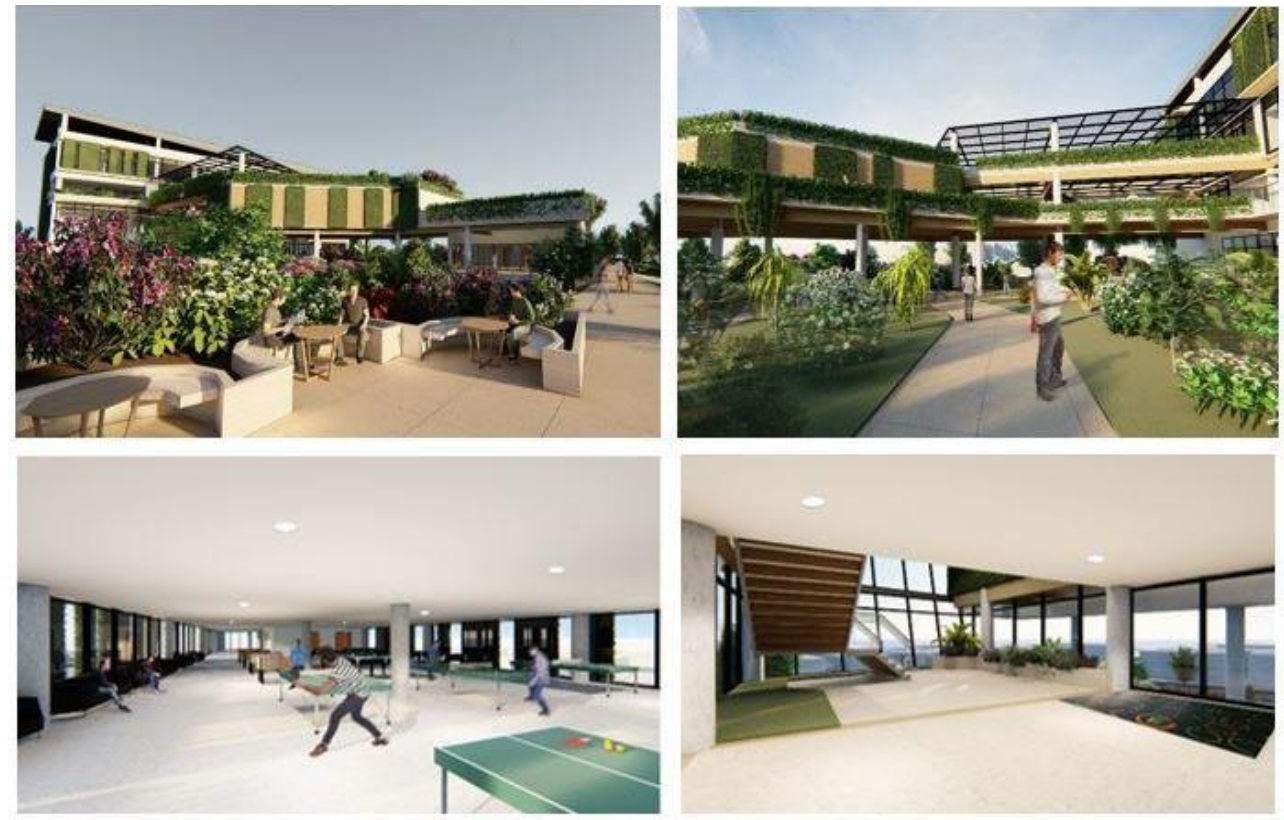


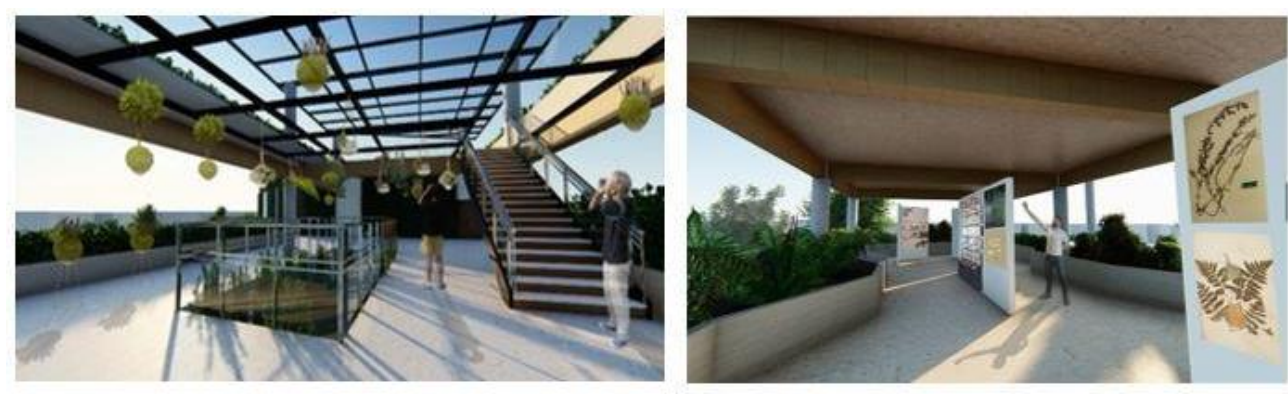

Gambar 17. Perspektif Proyek

Sumber: Penulis, 2020

\section{KESIMPULAN DAN}

Penerapan metode fenomenologi untuk menganalisa dan melihat kebutuhan warga setempat dan mengintegrasikan konsep biofilik dalam merancang third place di Kedoya Utara menghasilkan rancangan proyek Fasilitas Rekreasi Interaktif Tanaman Hias. Proyek ini berperan sebagai wadah arsitektur third place yang menimbulkan rasa saling memiliki yang dapat mewadahi, memenuhi kebutuhan, dan mendorong interaksi sosial masyarakat setempat serta menjadi ruang jeda antara first place dan second place. Dengan program berupa area tanaman hias yang terbagi menjadi beberapa zona, instalasi tanaman hias, gallery, dan game center seperti permainan papan dan meja dan program penunjang berupa area makan, cafe, ruang serbaguna yang didasari oleh kebutuhan mendasar warga Kedoya Utara yang bersifat netral dan dengan melihat potensi dari kawasan maka dengan begitu dapat memenuhi kebutuhan warga setempat. Tanaman hias dapat menjadi pemenuhan salah satu aspek kebutuhan manusia untuk tetap dekat dengan alam yang kemudian di integrasikan dengan konsep biofilik agar dapat memaksimalkan potensi dari tanaman itu sendiri. Program yang interaktif dapat menjadikan tanaman bukan sekedar elemen dekoratif namun dapat menjadi sarana hiburan yang menarik, mendorong rasa ingin tahu, dan memberikan sense of place yang dapat berpengaruh bagi emosi dan psikologi seseorang di satu sisi secara tidak langsung hal ini dapat menjadi sarana untuk membuat tanaman hias lebih di kenal masyarakat luas. Sebaiknya dalam merancang third place perlu dilihat masalah dan potensi dari kawasan tersebut sehingga dapat menjadi ciri khas kawasannya dan menjadi jawaban permasalahan warga setempat. Penting untuk sebuah third place memiliki program yang netral sehingga dapat digunakan semua kalangan dan perlu melihat kebutuhan kawasan agar program menjadi tepat.

\section{REFERENSI}

Ahlawat, J. (2016). Architectural Phenomenology exploring the experiential potentiality of architecture. Retrieved Februari 26, 2020, from issuu: https://issuu.com/jyotiahlawat/docs/final_research_paper_for_issuu

Bloom, L. B. (2020). Ranked: The World's 20 Most Stressed-Out Cities. Retrieved Juli 23, 2020, from Forbes: https://www.forbes.com/sites/laurabegleybloom/2020/01/30/rankedworlds-20-most-stressed-out-cities/\#4b57c648519c

Browning, W., Ryan, C., \& Clancy, J. (2014). 14 Patterns of Biophilic Design. New York: Terrapin Bright Green, LLC.

Evanindya, F. (2011). Aroma Dalam Ruang Arsitektur. Depok: Universitas Indonesia.

Holtman, A., \& Ryan, K. (2012). The Biophilic Concept: Framing Learning with Nature. Environmental Design Research Association EDRA43 Emergent Placemaking, (p. 2). Seattle.

Kellert, S. R., \& Calabrese, E. F. (2015). The Practice of Biophilic Design. London: Terrapin Bright LLC.

McLeod, S. (2020). Maslow's Hierarchy of Needs. Retrieved Februari 26, 2020, from SimplyPsychology: https://www.simplypsychology.org/maslow.html 
Mursito, B., \& Prihmantoro, H. (2011). Tanaman Hias Berkhasiat Obat. Jakarta: Penebar Swadaya.

Oldenburg, R. (1997). The Great Good Place (2nd ed.). Cambridge: Da Capo Press.

Tjahjono, G. (2000). Metode Perancangan Suatu Pengantar Untuk Arsitek Dan Perancang. Universitas Indonesia 